\title{
The Influence of Age and Gender
}

\section{on the Value Orientation}

\section{of Extreme Sports Participants}

Authors' contribution:

A) conception and design of the study

B) acquisition of data

C) analysis and interpretation of data

D) manuscript preparation

E) obtaining funding

\section{Éva Pólus-Thiry ${ }^{1 \text { A-E }}$, Csaba Rédei ${ }^{2}$ C-E}

${ }^{1}$ Semmelweis University in Budapest, Hungary

${ }^{2}$ Corvinus University, Budapest, Hungary

ABSTRACT

Research has shown that the popularity of extreme sports is on the rise in Hungary just as in developed countries. While we cannot question the influence of the press, it is very likely that shifts and changes in the value orientation of a society also play an important role in fostering the process. In the first stage of the present study, the value orientation of a group of Hungarian people involved in action sports is mapped where the values are arranged into a latent structure using principal component analysis. In the second stage of research, it is checked whether the examined group is a homogenous community regarding their value orientations, and researchers examine if two variables - age and gender - significantly influence the value orientations of the respondents. Our conclusion is that there is little difference between group members regarding their high preferences for community values and the low preferences for traditional values, but age and gender significantly influence respondents' attitudes to post-materialist values and partially those to materialist values. Younger participants report higher preferences for both materialist and postmaterialist values, while females attribute higher importance to post-materialist values.

KEYWORDS $\quad$ action or extreme sports, age, gender, value orientation

\section{Introduction}

Although this topic has not been well researched, we can see that alternative adventure sports are becoming more and more popular in Hungary. Such action sports propagate new forms of exercise, new instruments, and even more importantly, new values endorsed by the participants.

Research has been conducted for several decades into the background of popularity of extreme sports. Marvin Zuckerman et al. (2000) concluded that motivations are primarily determined by biological factors. Kusz (2004) associated the emergence and spread of extreme sports with identities, values, and desires that were articulated, endorsed, and praised in the press.

Many scholars think that encouraging factors can be found in the changes of value orientation. Fundamental changes took place in the last decades of the $20^{\text {th }}$ century when counterculture movements of young people emerged. A new zeitgeist appeared which influenced culture, social and individual norms, value preferences, and ways of thinking. 
Ihab Habib Hassan introduced a new term, "post-modern society”, in 1971. Predominant factors in this society are uncertainty, doubts and imbalance, where values can easily be endorsed and questioned at the same time. Preuss-Lausitz (1997) thinks that we live in a society of risks that can be characterized by ambivalent values such as differentiation and pluralization, diversity and individualization, separation and rejection of the mainstream ideas, but also aspirations for belonging to a community, or for recognition and affection of the community.

Inglehart (1997) maintains that unprecedented economic performance and economic security brought us to post-modernization in the last quarter of the $20^{\text {th }}$ century. While we saw the hegemony of materialist values in most of the course of human history, the age of post-modernization is largely characterized by the appearance of post-materialist values. Materialist values are basically related to two factors: accumulation of financial means and the search for physical security. Post-materialist values, on the other hand, stress the importance of things such as trust and co-operation, spiritualism and self-actualization, freedom and health. Post-materialist values have their roots in post-modernization as if the context in which value orientation is developed is characterized by economic security and a continuous development, society will endorse postmaterialist values. Inglehart's ideas are based on the scarcity hypothesis, which means that people place great value on things that are difficult to attain. Since welfare societies had tended to have a high level of economic stability and a high level of subjective well-being until the recent crises, the value orientation of the population in these societies that were formerly dominated by materialist values would necessarily change. Inglehart emphasized that post-modernization and the dominance of post-materialist values were both supported by positive economic changes.

Value orientations of welfare societies are mainly influenced by the zeitgeist of post-modernism, which is represented by high preferences for post-materialist values. Materialist values such as wealth/richness or power/leadership are losing their importance as individuals refuse the ideas of oppression, power, and authority. They become committed to post-materialist values (such as peaceful world, true friendship, inner harmony, creativeness, varied life experiences and an interesting life) at the same time.

A basic feature of our post-modern age is that individuals do not ask questions to find out if something is rational or true. The only thing that matters to them is the fact whether they like it or not. Joy of life becomes the life objectives of many people thus resulting in a society where everyone can choose and endorse their own "values" (Preuss-Lausitz, 1997).

Action sports participants focus on risk-taking and put faith in their own skills. They seem to endorse values such as free and independent choice, self-expression, and creativity. It is obvious that the post-modern zeitgeist and a shift to post-materialist values deeply encourage the spread and popularity of extreme sports.

\section{Developments in Hungary}

Post-modernization reached Hungary due to technological development, the changing role of the media, and globalization in the 1980s; however, the historic past and economic conditions of the country caused its influence to be seen only some decades later.

As Hungary was a country in the Eastern Bloc, the preferred values of the population were mainly influenced by the official ideology, which resulted in a peaceful world, a stable family, and the security of the homeland being the mostly endorsed values. Due to the political change, these values had completely eroded by the 1990s (Füstös \& Szakolczai, 1994).

The change of regime in 1989 involved a new path in the political, economic, and social development of the country. Revolutionary changes in preferred values were induced by the disappearance of Soviet influence, the emergence of the multi-party system replacing the one-party system, accession to NATO, private ownership over public ownership, the yet unknown phenomena of unemployment, and inflation.

While economic wealth was somewhere in the middle of the list of value ratings of the population in the beginning of the 1980s, it came up to the fifth position by the 1990s. This is not a surprise if we consider 
the fact that the image of Western welfare societies encouraged the population to set new objectives, on the one hand, and at the same time the opportunities of wealth accumulation proliferated and changed the uniform economic position of the individuals who were primarily supported by the caring state, on the other hand (Beluszky, 2000). Along the officially registered economy dominated by national re-distribution, a "second economy" emerged which was primarily influenced by market forces.

These results tally with Inglehart's findings on the basis of which he characterized the Hungarian people as being driven rather by materialist values regarding the total value map, while they re demonstrate introverted, closed personalities and endorse a rational set of values (Inglehart, 1997).

Naturally, individuals are continuously reflecting the changes of the environment, while they are adapting to the elements of post-modern culture, thus producing a continuous shift in their value orientations. Thanks to this phenomenon, research conducted into young people's orientations at the beginning of the new millennium reports a shift toward post-materialist values. Values such as a peaceful world, true friendship, or love are gaining more and more importance (Bauer, 2002). However, findings of the European Value Survey in 2008 showed that only $8 \%$ of Hungarians had their value orientation completely dominated by postmaterialist values, while $33 \%$ were mainly influenced by materialist values, and $59 \%$ represented a mixed attitude to values (Kmetty, 2011).

\section{Objectives}

We have already demonstrated in one of our previous studies that post-materialist values gained importance in the value orientation of people involved in extreme sports while the mainstream society continues to endorse primarily materialist values in Hungary. Action sports, one of the fundamental domains of the "post-materialist revolution" (Inglehart), is a shift toward post-materialist values in the individual's orientation. People involved in extreme sports tend to have lower preferences for materialist values and higher preferences for post-materialist values.

In our present study we have two objectives. According to the socialization theory of Inglehart, value orientation is developed in adolescence and it is formed by the underlying material conditions at that age, which means that value preferences of the individual do not change in the subsequent years. No change in the value preferences is possible in the individual's life; real changes take place only through generations (Inglehart, 1997). On the basis of this assumption, we want to draw the value map of the people participating in our survey depending on the variable "age". One of our goals is to determine whether there is any difference in the orientations of 30-40-year-old people, who were socialized during the socialist regime, as well as the orientations of those below 25, who developed their value preferences after the change of regime.

Some studies in 2004 demonstrated that there were significant differences between the life principles of young males and females in Hungary. Females had high preferences for emotion-related values (emotional stability, quality of personal relationships) while males mainly endorsed values linked to sense of freedom, force, and power (Bauer-Szabó, 2005). We also wanted to find out in our research if the variable "gender" had any influence on the value orientation of the participants.

Before conducting our research we have made the following pre-assumptions:

- On the basis of Inglehart's socialization hypothesis, older generations are likely to report better ratings for materialist values while younger generations, who were socialized after the change of regime, would probably have higher preferences for post-materialist values compared to the mean of the examined sample of action sports participants.

- There are some natural differences between value preferences of the two genders. We expect to see females having higher preferences for values related to community life and emotions, and males reporting better ratings for values linked to sense of freedom, material stability, and existential security (partly materialist values). We postulated that whether the individual pursued some kind of action sport or not would not influence the assumed differences between the orientations of males and females. 


\section{Methods}

Any research into extreme sports participants encounters the problem of sample selection. We can find the main reasons for this problem in the two basic features of adventure sports. On the one hand, the fundamental aspiration of participants is to take full advantage of the opportunities of technological development and surpass both the limits inherent in nature and the limits of individual performance through risk-taking. The introduction of spectacular elements, what is more, the creation of new sports, only depends on the creativity of the people involved. Thanks to these special circumstances, new sports are developed (and skipped) every day, which means that it is impossible to compile a list of all the sports involved that would be valid in the long run. On the other hand, whether the participant can be deemed as "an extreme sportsman/woman" is highly subjective and is based on the self-image of the individual. In many cases society categorizes people as pursuing extreme sports while they themselves do not share the same view of their activities.

The 250 people that took part in our survey partly belonged to sport clubs and partly were selected using snowball sampling. Respondents included 46 skateboarders, 41 mountain bikers, 46 cavers, 24 mountain climbers and rock climbers, 24 wall climbers, 55 skydivers, 14 divers and free divers.

We have considered two aspects for selecting the sports to be examined.

It is important to see the costs involved in the various sports. As expensive sports equipment goes hand in hand with a materialist attitude, we try to include sports that are attached to three different price levels to get a wide picture. Comparing the costs of sports, we can say that the lowest level of cost is involved in skateboarding and mountain biking; mountaineering, wall climbing, caving and diving represent a middle level of costs, while you need a relatively larger investment of money for skydiving. The second aspect of the selection is the individual or collective nature of the sport: whether they can be pursued alone or in the company of others. We attempt to include a mixed spectrum of sports from this aspect. Some sports that can be practiced alone such as skateboarding, mountain biking or skydiving might be more interesting to people with an individualistic attitude while other sports - caving, mountain climbing, rock climbing, wall climbing, and diving - that you usually pursue in the company of people would necessarily attract individuals who might have high preferences for community values.

Since the basic attributes of the total population of extreme sports participants are unknown, the sample is unrepresentative, but we do estimate that our sample would not include a significantly different structure of value orientation from that of the total population of extreme sports participants.

Data were collected through an online questionnaire that contained closed questions. A value scale by Tibori-Bauer (a Likert-type scale of 17 items) was used to measure the value preferences of the respondents. This value scale is a combination of Inglehart's scale and the Rokeach Value Survey. It divides the 17 items into 4 categories of values: materialist values (aesthetics, wealth/richness, and power/leadership); traditional values (respect of traditions, religion, national pride, and social order); post-materialist values (varied life experiences, interesting life, freedom, creativity, and peaceful world); and values of the private sphere (true friendship, true love, inner harmony, and stable family) (Bauer \& Tibori, 2002). This set of values was completed with values that society usually associates with people involved in extreme sports (sincerity, carefulness, solidarity, fair-play, knowledge, health, responsibility, recklessness, risk-taking, team spirit, assistance, and courage).

Values involved in our research are typically used in surveys on culture and life style, but values such as creativeness, risk-taking, recklessness, and responsibility - under certain conditions - can be applied to measure behavior patterns in sport as well.

To produce a map of value orientation, respondents had to rank values on a scale from 1 (not important at all) to 4 (very important). 


\section{Results and discussion}

First, we calculated the mean scores of the various values. The ratings of the values on the basis of the scores can be seen in Table 1.

Table 1. Ratings of the values

\begin{tabular}{lclc}
\hline $\begin{array}{l}\text { How important do you } \\
\text { consider ......... in your life? }\end{array}$ & Mean & $\begin{array}{l}\text { How important do you } \\
\text { consider ........ in your life? }\end{array}$ & Mean \\
\hline health & 3.8 & knowledge & 3.5 \\
sincerity & 3.8 & team spirit (1) & 3.4 \\
inner harmony & 3.7 & interesting life (3) & 3.3 \\
true friendship & 3.7 & solidarity (1) & 3.2 \\
freedom & 3.7 & courage & 3.0 \\
carefulness (1)* & 3.7 & national pride (2) & 2.8 \\
assistance (1) & 3.7 & respect of traditions (2) & 2.6 \\
peaceful world & 3.6 & social order & 2.6 \\
stable family & 3.6 & aesthetics & 2.5 \\
true love & 3.6 & wealth/richness (4) & 2.4 \\
fair-play & 3.6 & risk-taking & 2.4 \\
responsibility (1) & 3.6 & recklessness & 1.9 \\
varied life experiences (3) & 3.5 & power/leadership (4) & 1.7 \\
creativity (3) & 3.5 & religion (2) & 1.6 \\
\hline
\end{tabular}

* Numbers in the brackets show which factor the values belong to.

Source: own study.

In the second stage of analysis, the number of values involved in the examination was reduced by principal component analysis. The following four factors were identified: community values (1), traditional values (2), post-materialist values (3), and materialist values (4). The Kaiser-Meyer-Olkin Test result (0.719) suggests there is a connection of medium strength between the values. The total variance explained by the four factors is nearly $60 \%$ of information, which is a fairly good result. Our structure is comprised of the following values:

- factor 1. (community values, 5 items): carefulness, solidarity, responsibility, team spirit, assistance

- factor 2. (traditional values, 3 items): religion, respect for traditions, national pride

- factor 3. (post-materialist values, 3 items): varied life experiences, interesting life, creativity

- factor 4. (materialist values, 2 items): wealth/richness, power/leadership

Table 1. demonstrates the factors to which the various values in the list belong. Values in factor 1 have the highest scores followed by post-materialist values in factor 3. Traditional values in factor 2, and especially materialist values in factor 4 , have the lowest ratings.

There are two sets of values that are omitted from our model. Private sphere values and values of general interest such as health or knowledge are important to everyone, and these does not depend on the individual's background, interests or habits.

Values related to risk-taking are also omitted from the model. It might be a surprise why these values were rated with such low scores in the respondents' perception. Anyone could argue that these values must be of primary importance to participants, as action sports is a domain where individuals can show off their special qualities related to sport activities. Participants certainly have a higher propensity for risk-taking (at least for physical risks) than do other people. This paradox originates from the different perception of special situations experienced during the sports activity. Most participants do not consider these situations dangerous, while society maintains that the very same situations are life-threatening (Rinehart, 2005). People involved in extreme sports tend to avoid excessive risks and dangers themselves. We do question whether there is any difference between the attitudes of participants and non-participants to the risks. The only difference comes from the different judgment of particular situations. For this reason values related to risktaking are not included in the model to avoid possibly distorted results. 
Following the analysis of the value orientation of the participants, we examine whether the age and the genders of the respondents have any influence on the value preferences. Our basic aim is to measure the influence.

We use the variables of standard normal distribution (mean $=0$, standard deviation $=1$ ) produced in the principal component analysis. The positive scores refer to higher preferences, and the negative scores refer to lower preferences in the individual's orientation.

ANOVA is used to check the variance between the groups of the various value dimensions. We have identified five age groups: below 20 years old (1), 20-25 years old (2), 25-30 years old (3), 30-40 years old (4) and above 40 years old (5). Our sample contains $22,28,46,87$, and 67 respondents in the different age groups, respectively. Regarding the genders, males are overrepresented in the sample: 191 males and 59 females took part in the survey.

As a first result of the analysis, our conclusion is that neither of the two variables (age and gender) have any influence on two value dimensions, that is, the community values and the traditional values. It is not a surprise to us that preferences for community values are unaffected. Community values seem to be endorsed by all the participants, and it does not depend on the fact that the sport is practiced individually or in groups of other people. These values transmit the experience of companionship. It often occurs that action sports participants get involved in difficult situations where they desperately need the help of others. Most of these sports are primarily practiced in groups (Wheaton, 2003) where group members are close friends in many cases. This is why preferences for community values are not influenced by age or gender.

Regarding the influence of the variables on the preferences for traditional values, we found that the results are a bit of a surprise. We know that traditional values are more important to people belonging to older age groups of youth (Bauer-Szabó, 2005). One might ask the question of why we cannot see the same influence of age in our sample. The explanation is probably that participants are ipso facto not concerned with traditional values without respect to their age. The influence of an older age is offset by another effect, that is the probability that only those people would continue practicing extreme sports until their older age who are definitely not attracted to traditional values.

Our analysis indicates that age and gender, however, significantly influence the preferences for postmaterialist and materialist values. Let us first examine the effect on post-materialist values. Table 2 . demonstrates the influence of age on the attitude to post-materialist values.

Table 2. Correlation between age and preferences for post-materialist values

\begin{tabular}{|c|c|c|c|c|c|c|}
\hline & $\begin{array}{c}\text { Age group } 1 \\
\text { below } 20 \text { years } \\
\text { old } \\
{[\mathbf{N}=22]} \\
\end{array}$ & $\begin{array}{c}\text { Age group } 2 \\
20-25 \\
\text { years old } \\
{[\mathrm{N}=28]} \\
\end{array}$ & $\begin{array}{c}\text { Age group } 3 \\
25-30 \\
\text { years old } \\
{[\mathrm{N}=46]} \\
\end{array}$ & $\begin{array}{c}\text { Age group } 4 \\
30-40 \\
\text { years old } \\
{[\mathrm{N}=87]} \\
\end{array}$ & $\begin{array}{c}\text { Age group } 5 \\
\text { above } 40 \\
\text { years old } \\
{[N=67]} \\
\end{array}$ & {$[\mathrm{N}=250]$} \\
\hline Mean & 0,116 & 0,395 & $-0,063$ & 0,108 & $-0,297$ & 0,001 \\
\hline SD & 1,1 & 0,844 & 0,891 & 0,929 & 1,127 & 1,002 \\
\hline
\end{tabular}

Source: own study.

Scores of post-materialist values of the individual tend to decrease with an older age; however, this tendency is not continuous. The age group 2 (20-25-year-olds) reports the highest preferences and the age group 5 (above 40 years old) reports the lowest preferences for post-materialist values. The correlation is significant at the $5 \%$ level $(\mathrm{p}=0,019)$.

The findings have partly justified our first pre-assumption. We expected the people in younger age groups to have higher preferences for post-materialist values when compared to older generations. The analysis has shown that these values are really more important to young people. It shows the effect described by Inglehart: younger people are more responsive to post-materialist values than older people. Socialization after the change of regime could also have an effect on these generations. If we regard the importance of post-materialist values, a younger age seems to be more determinative than involvement in action sports. 
Now let us examine the preferences for materialist values. Table 3 shows the influence of age on the attitude to materialist values.

Table 3. Correlation between age and preferences for materialist values

\begin{tabular}{lcccccc}
\hline & $\begin{array}{c}\text { Age group 1 } \\
\text { below 20 } \\
\text { years old } \\
{[\mathbf{N = 2 2}}\end{array}$ & $\begin{array}{c}\text { Age group 2 } \\
\mathbf{2 0 - 2 5} \\
\text { years old } \\
{[\mathbf{N = 2 8}}\end{array}$ & $\begin{array}{c}\text { Age group 3 } \\
\mathbf{2 5 - 3 0} \\
\text { years old } \\
{[\mathbf{N = 4 6}}\end{array}$ & $\begin{array}{c}\text { Age group 4 } \\
\mathbf{3 0 - 4 0} \\
\text { years old } \\
{[\mathbf{N}=\mathbf{8 7}]}\end{array}$ & $\begin{array}{c}\text { Age group 5 } \\
\text { above 40 } \\
\text { years old } \\
{[\mathbf{N = 6 7 ]}}\end{array}$ & $\begin{array}{c}\text { Total } \\
{[\mathbf{N = 2 5 0 ]}}\end{array}$ \\
\hline Mean & 0,368 & 0,176 & 0,201 & $-0,113$ & $-0,181$ & 0,001 \\
SD & 0,979 & 1,146 & 0,894 & 0,980 & 0,992 & 0,998 \\
\hline
\end{tabular}

Source: own study.

Age obviously has an effect on preferences for materialist values, though their correlation at $5 \%$ level is not yet significant $(\mathrm{p}=0,059)$. Although we have proven the existence of the correlation, this is the opposite direction than we previously expected. Older age does not increase, but decreases the likelihood of high preferences of the individual for materialist values. We might find an explanation for this in the differences of involvement in action sports. Any interest in extreme sports increases the likelihood of the individual being more attracted to thrill seeking than being under the influence of material values. The longer the participant has been practicing action sports (and probably belongs to older age groups), the more likely it is that they attribute low importance to materialist values. This condition seems to be offsetting the effect described by Inglehart: due to deeper involvement in action sports people in older age groups are more resistant to material values, compared to people in younger age groups. This effect can be seen in all the five age groups (Table 3). There are only two groups where we cannot see remarkable differences in the preferences: age group 2 (20-25 years old) and age group 3 (25-30 years old) report more or less the same attitude toward materialist values. This is, however, not a surprise if we consider that these generations have more or less similar living conditions and views of life.

If we divide our sample into two age groups, the effect of age on the preferences for materialist values becomes more obvious (Table 4). The table contains two groups of people (above 30, $\mathrm{N}=96$ and below 30, $\mathrm{N}=154)$. Younger respondents have higher preferences $(\mathrm{M}=0.232)$ while older respondents have lower preferences $(M=-0.143)$ for materialist values; the correlation is significant at the $5 \%$ level $(p=0,004)$.

Table 4. Correlation between age and preferences for materialist values in the case of two age groups

\begin{tabular}{lccc}
\hline & $\begin{array}{c}\text { Age group 1 } \\
\text { above 30 } \\
\text { years old } \\
{[\mathbf{N}=\mathbf{9 6}]}\end{array}$ & $\begin{array}{c}\text { Age group 2 } \\
\text { below 30 } \\
\text { years old } \\
{[\mathbf{N = 1 5 4}}\end{array}$ & $\begin{array}{c}\text { Total } \\
{[\mathbf{N}=\mathbf{2 5 0}]}\end{array}$ \\
\hline Mean & 0,232 & $-0,143$ & 0,001 \\
SD & 0,985 & 0,982 & 0,998 \\
\hline S
\end{tabular}

Source: own study.

At the last stage of our analysis it is examined whether the gender of the participants has any influence on value orientation. Although we anticipated that there would be some differences between the genders in their attitudes towards community values, our findings did not support the pre-assumptions. Community values are highly endorsed by most people in the sample without respect to their gender. Some significant correlation is seen, however, regarding the attitudes to post-materialist values (Table 5).

Table 5. Correlation between gender and preferences for post-materialist values

\begin{tabular}{lccc}
\hline & $\begin{array}{c}\text { Males } \\
{[\mathbf{N = 1 9 1}]}\end{array}$ & $\begin{array}{c}\text { Females } \\
{[\mathbf{N = 5 9 ]}}\end{array}$ & $\begin{array}{c}\text { Total } \\
{[\mathbf{N}=\mathbf{2 5 0}]}\end{array}$ \\
\hline Mean & $-0,086$ & 0,282 & 0,001 \\
SD & 1,054 & 0,760 & 1,002 \\
\hline
\end{tabular}

Source: own study.

Our last table demonstrates that males have lower preferences for post-materialist values than females. The correlation is significant at the $5 \%$ level $(\mathrm{p}=0,014)$. We know that emotions play a key role among postmaterialist values. Therefore, the findings partly support our second pre-assumption: although males do not 
report higher preferences for materialist values, post-materialist values definitely are more important to females.

\section{Conclusions}

To sum up our results: we maintain that though members of extreme sports subcultures tend to have similar value orientations, still they cannot be deemed as homogenous communities. Although we did not see remarkable differences in the preferences for community values and traditional values in our sample, people do have different attitudes towards the other two sets of values: materialist and post-materialist values.

Age plays a key role in influencing the value orientations of the respondents. As age increases, preferences for materialist values fall. We have declared that this correlation is likely to be caused by different levels of involvement in action sports: the longer you practice adventure sports, the more likely it is that you primarily have a positive attitude to thrill-seeking and you are less concerned with values of the material world. Nevertheless, lower preferences for materialist values are not necessarily accompanied by higher preferences for post-materialist values. People in younger age groups respond more to post-materialist values as compared to people in older age groups. As for the influence of gender, we have seen that attitudes towards community values are unaffected, yet females do attribute more importance to post-materialist values, which are partly determined by emotions, than males do. Post-materialist values in our sample are mostly preferred by females regarding the gender and by younger age groups regarding the age of the respondent.

\section{References}

Bauer, B. (2002). Az ifjúság viszonya az értékek világához /Youth attitudes on values/. In A. Szabó, B. Bauer \& L. Laki (Eds.), Ifjúság 2000 /Youth 2000/ (pp. 195-208). Budapest: Nemzeti Ifjúságkutató Intézet /National Institute for Youth Research/.

Bauer, B., \& Tibori, T. (2002). Az ifjúság viszonya a kultúrához /Youth attitudes to culture/. In A. Szabó, B. Bauer \& L. Laki (Eds.), Ifjúság 2000 /Youth 2000/ (pp. 173-194). Budapest: Nemzeti Ifjúságkutató Intézet /National Institute for Youth Research/.

Bauer, B., \& Szabó, A. (2005). Ifjúság 2004. Gyorsjelentés /Youth 2004, Report/. Budapest: Mobilitás Ifjúságkutató Iroda /Mobilitás Youth Research Office/.

Beluszky, T. (2000). Értékek, értékrendi változások Magyarországon 1945 és 1990 között /Changes of the value system in Hungary, 1945-1990/. Korall 2000/ösz/Coral 2000/autumn/, 137-154.

Füstös, L., \& Szakolczai, Á. (1994). Értékek változásai Magyarországon, 1978-1993 /Value changes in Hungary, 19781993/. Szociológiai Szemle /Review of Sociology/, 1, 57-90.

Hassan, I.H. (1971). The dismemberment of Orpheus: toward a postmodern literature. Oxford: Oxford University Press.

Inglehart, R. (1997). Modernization and Postmodernization. Cultural, Economic and Political Change in 43 Societies. Princeton: Princeton University Press.

Kmetty, Z. (2011). Úton a posztmaterialista társadalom irányába? /Toward a post-materialist society? /Lelkiségi és Kulturális Folyóirat /Journal of Spiritualism and Culture/ Retrieved from http://www.asziv.hu/?newart=14\&newmag =19\&show=arch, November 05, 2011.

Kusz, K. (2004). Extreme America: The Cultural Products of Extreme Sports in 1990s America. In B. Wheaton (Ed.), Understanding Lifestyle Sports: Consumption, Identity and Difference (pp. 197-215). London: Routledge.

Preuss-Lausitz, U. (1997). A fiatalok világa a posztmodern társadalomban /Youth in the postmodern society/. Új Pedagógiai Szemle /New Review of Pedagogy/, 7-8, 192-197.

Zuckerman, M., \& Kulman, D.M. (2000). Personality and Risk-Taking. Common Biosocial Factors. Journal of Personality, 68(6), 999-1029.

AUTHOR'S ADDRESS: $\quad$ Éva Pólus-Thiry

c/o MTA SZTAKI

Kende u. 13-17

H-1111 Budapes Hungary

Email:thiry@sztaki.hu 